\title{
Karyological Studies in Gossypium herbaceum Cultivars of Iran
}

\author{
Masoud Sheidai ${ }^{1}$, Parviz Vojdani ${ }^{2}$ and Omran Alishah ${ }^{3}$ \\ ${ }^{1}$ Biol. Dep. Shahid Beheshti Univ. Tehran. Iran \\ ${ }^{2}$ Agri. Res. Center. Tehran. Iran \\ ${ }^{3}$ Dep. Plant Breeding. Tarbiat Modares Univ. Tehran. Iran
}

Accepted September 20, 1996

Cotton is one of the most important crops of Iran, cultivated in different regions of the country. Continuous cultivation of improved and uniform cultivars leads to genetic erosion rapidly, hence there is an urgent need to try and assemble whatever diversity still available (Rao and Riley 1994, Fitzgerald 1989).

Gossypium herbaceum is one of the A-genome cottons which is diploid and is potentially important resource for cotton breeding programs (Stanton et al. 1994). Though different cultivars of $G$. herbaceum were collected in Iran National Gene Bank from various regions, no information was available on morphology or cytogenetics of these plants until initiation of present study. Present paper considers karyological studies of forty-two G. herbaceum cultivars of Iran.

\section{Materials and methods}

Forty-two Gossypium herbaceum cultivars available in Iran National Gene Bank were planted according to randomized completely block design in Varamin cotton research center during 1994-95. Each cultivar was planted on a line from which 10 plants were selected randomly and used for morphological and cytological studies.

Seeds collected from these plants were germinated in petridish plates after removing the linters and freshly grown roots were used for karyological preparations. The method of pretreatment and fixation followed as before (Sheidai et al. 1996a). Different stains were tried and the best result was obtained using $2 \%$ acetic-orcein.

Karyotypes were compared using total form percentage (Forni-Martin et al. 1994), ratio of the longest to shortest chromosome (Verma 1980), coefficient of variation (Verma 1980), S\%, difference of the range of relative length (D.R.L.) (Gennur et al. 1988b) and total volume (Datta and Agarwal 1992).

Karl Pearson coefficient of correlation was determined for total length of chromosomes, length of the long arms, length of the short arms and L/S ratio (Verma 1980), chromosomes were described according to Levan's terminology (Levan et al. 1964).

Factorial analysis was performed on karyological data with cultivars and chromosomes as the two factors.

Cluster analysis using UPGMA method (Bernardello et al. 1994, Sheidai et al. 1996a) and principal coordinate analysis (Pickersgill et al. 1976) were used to group karyotypically similar cultivars. NTSYS-pc version 1.4 was used for multivariate statistical analysis. For principal coordinate analysis data were first standardized (mean $=0$ and variance $=1$ ). Taxonomic distance was determined from standardized data, followed by eigen value analysis and ordination of cultivars on the first two principal coordinate axis (Pickersgill et al. 1976).

Principal component analysis was performed on the size of chromosomes and chromosome 
arms in each karyotype to indicate the most variable chromosome/chromosome arms. For conveniance from each cluster a single representative was selected for PCA analysis. For PCA analysis data were first standardized and then product-moment correlation was determined (Sneath and Sokal 1973). Eigen values were determined from transformed data and ordination of cultivars was performed on the first two PCA axis (McClintock and Waterway 1994).

\section{Results and discussion}

Names of the cultivars, their karyotype formulae and number of SAT-chromosomes are presented in Table 1 . All the cultivars possessed $2 n=26$ chromosome number but varied with regard to number of SAT-chromosomes (ranging from 1 to 3 ) and the chromosomes carrying

Table 1. Names of cultivars, SAT-chromosomes and karyotype formulae.

\begin{tabular}{|c|c|c|c|c|}
\hline Cultivar & $2 n$ & No. SAT & SAT-Chromosomes & Karyotype formulae \\
\hline 1. Kerman & 26 & 1 & 1 & $1 \mathrm{M}+12 \mathrm{~m}$ \\
\hline 2. Kashan 12 & 26 & 1 & 1 & $3 \mathrm{M}+10 \mathrm{~m}$ \\
\hline 3. Ghom 1 & 26 & 2 & 1,3 & $13 \mathrm{~m}$ \\
\hline 4. Giroft & 26 & 2 & 1,2 & $1 \mathrm{M}+12 \mathrm{~m}$ \\
\hline 5. Garmsar 60 & 26 & 3 & $1,2,3$ & $13 \mathrm{~m}$ \\
\hline 6. Lasjard & 26 & 2 & 1,2 & $13 \mathrm{~m}$ \\
\hline 7. Kerman B. & 26 & 3 & $1,2,3$ & $13 \mathrm{~m}$ \\
\hline 8. Neiriz. R. & 26 & 2 & 1,8 & $13 \mathrm{~m}$ \\
\hline 9. Ghom 52 & 26 & 2 & 1,3 & $13 \mathrm{~m}$ \\
\hline 10. Neiriz GAZ & 26 & 2 & 1,2 & $13 \mathrm{~m}$ \\
\hline 11. Shahrood & 26 & 2 & 2,4 & $13 \mathrm{~m}$ \\
\hline 12. Damghan & 26 & 2 & 1,8 & $13 \mathrm{~m}$ \\
\hline 13. Shahreza & 26 & 2 & 1,3 & $13 \mathrm{~m}$ \\
\hline 14. Neishaboor & 26 & 2 & 1,4 & $13 \mathrm{~m}$ \\
\hline 15. Ardekan 1 & 26 & 2 & 3,4 & $13 \mathrm{~m}$ \\
\hline 16. Kashmar & 26 & 2 & 3,4 & $13 \mathrm{~m}$ \\
\hline 17. Kerman G. & 26 & 2 & 5,7 & $13 \mathrm{~m}$ \\
\hline 18. Hashemabad & 26 & 1 & 1 & $1 \mathrm{M}+12 \mathrm{~m}$ \\
\hline 19. Esfahan A. & 26 & 2 & 1,4 & $1 \mathrm{M}+12 \mathrm{~m}$ \\
\hline 20. Shooshtar & 26 & 2 & 1,4 & $1 \mathrm{M}+12 \mathrm{~m}$ \\
\hline 21. Gozagh & 26 & 2 & 1,4 & $1 \mathrm{M}+12 \mathrm{~m}$ \\
\hline 22. Mehrizsabz & 26 & 2 & 2,4 & $1 \mathrm{M}+12 \mathrm{~m}$ \\
\hline 23. Sabzevar & 26 & 2 & 1,3 & $2 \mathrm{M}+11 \mathrm{~m}$ \\
\hline 24. Marvast & 26 & 2 & 3,6 & $13 \mathrm{~m}$ \\
\hline 25. Rafsangan & 26 & 3 & $1,4,8$ & $1 \mathrm{M}+12 \mathrm{~m}$ \\
\hline 26. Mehrizbah & 26 & 2 & 1,5 & $13 \mathrm{~m}$ \\
\hline 27. Ghomgermez & 26 & 1 & 2 & $2 \mathrm{M}+11 \mathrm{~m}$ \\
\hline 28. Mehrizgod & 26 & 2 & 1,3 & $1 \mathrm{M}+12 \mathrm{~m}$ \\
\hline 29. Ardekan 2 & 26 & 2 & 1,2 & $13 \mathrm{~m}$ \\
\hline 30. Garmsar & 26 & 2 & 1,2 & $13 \mathrm{~m}$ \\
\hline 31. Alyafrangi & 26 & 3 & $1,2,6$ & $13 \mathrm{~m}$ \\
\hline 32. Bandarabas & 26 & 1 & 3 & $13 \mathrm{~m}$ \\
\hline 33. Rafsengan 2 & 26 & 1 & 4 & $1 \mathrm{M}+12 \mathrm{~m}$ \\
\hline 34. Rafsengan 3 & 26 & 2 & 1,2 & $13 \mathrm{~m}$ \\
\hline 35. Harat & 26 & 2 & 1,3 & $13 \mathrm{~m}$ \\
\hline 36. Ghom 3 & 26 & 2 & 2,5 & $13 \mathrm{~m}$ \\
\hline 37. Sabzevar 1 & 26 & 2 & 1,4 & $13 \mathrm{~m}$ \\
\hline 38. Arya & 26 & 1 & 1 & $2 \mathrm{M}+11 \mathrm{~m}$ \\
\hline 39. Mehrizgher & 26 & 1 & 2 & $3 \mathrm{M}+10 \mathrm{~m}$ \\
\hline 40. Mahalat & 26 & 1 & 3 & $13 \mathrm{~m}$ \\
\hline 41. Mehriz 4 & 26 & 2 & 1,4 & $13 \mathrm{~m}$ \\
\hline 42. Mehriz 5 & 26 & 2 & 1,3 & $2 \mathrm{M}+11 \mathrm{~m}$ \\
\hline
\end{tabular}


secondary constrictions (Fig. 1).

In most of the cases the longest chromosomes of the haploid set possessed secondary constriction but in few cases chromosomes 6,7 and 8 were SAT-chromosomes (Cultivars 8, 12, $17,24,25$, and 30 , Table 1). The size of SAT also varied from $0.31 \mu \mathrm{m}$ to $0.78 \mu \mathrm{m}$. Almost all
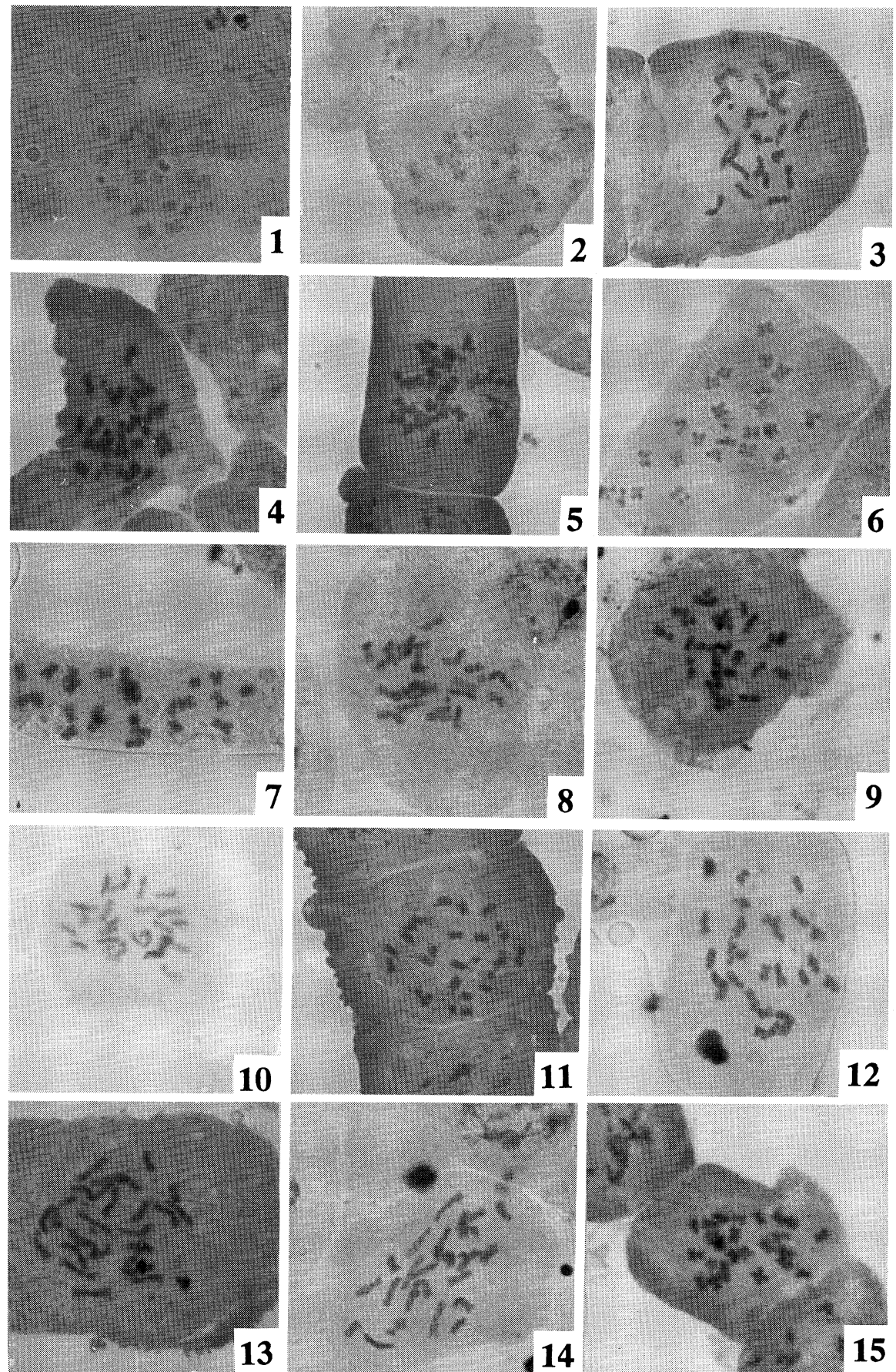

Fig. 1 

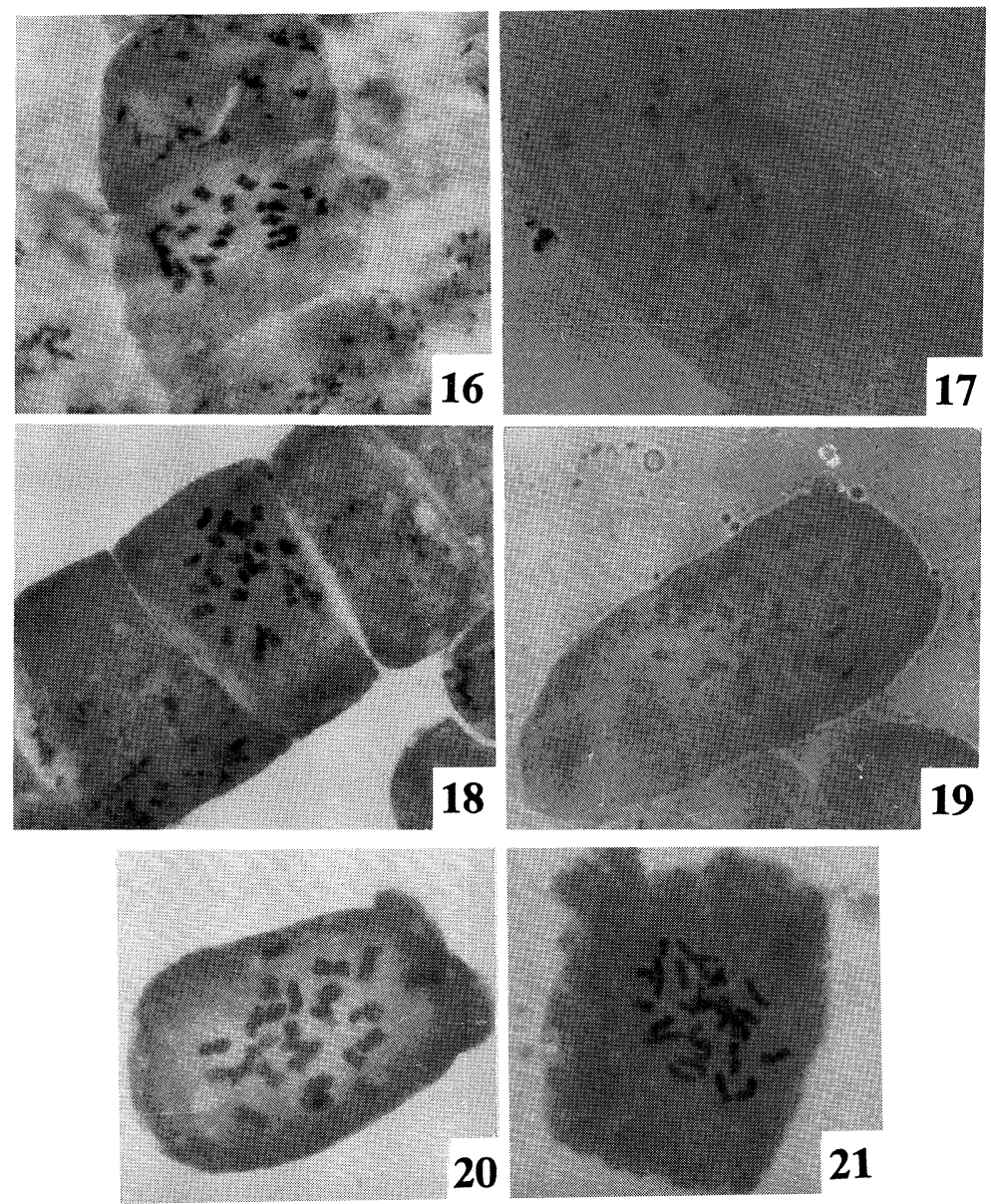

$9 \mu \mathrm{m}$

Fig. 1. Somatic chromosome numbers (cultivars sequence as Table 1). Figures 1 to 21 are for cultivars $2-4,6,8-15,18-20,22,25,26,29$ and 40 respectively.

the chromosomes were of $\mathrm{m}$ type except 1 or 2 chromosomes which were of $\mathrm{M}$ type (Table 1 ). Gennur et al. (1988a, b) reported occurrence of 8.27 metacentric chromosomes, 4.61 submetacentric and 0.11 acrocentric chromosomes in Asiatic cotton G. herbaceum. However present study does not show occurrence of acrocentric chromosomes in G. herbaceum cultivars available in Iran, indicating presence of genomic diversity in this species. As we shall see later on other analysis also support such, assumption.

Details of karyotypes are presented in Table 2. In general karyotypes were symmetrical with small size of chromosomes. The highest total length occurred in Sabzevar cultivar (46.46 $\mu \mathrm{m})$ and the least in Mahalat $(23.83 \mu \mathrm{m})$. The longest chromosome was observed in Sabzevar cultivar $(5.03 \mu \mathrm{m})$ while the shortest was observed in Mahalat $(1.2 \mu \mathrm{m})$. The higest C.V occurred in Ghom 52 (30.1) indicating more variation among its chromosomes, while the lowest value of C.V. occurred in Mehrizger (13.5).

The mean total length of chromosomes varied from $1.8 \mu \mathrm{m}$ (Mahalat) to $3.5 \mu \mathrm{m}$ (Sabzevar) and the mean total volume varied from 4.7 (Mahalat) to 9.3 (Mehrizbah).

Karl Pearson coefficient of correlation for total length of the chromosomes was $>0.95$ indicating homogeneity of the group but this value was reduced for the length of long arms $(0.72-0.96)$, length of short arms $(-0.01-0.61)$ and $\mathrm{L} / \mathrm{S}$ ratio $(0.31-0.96)$ indicating occur- 
Table 2. Cultivars and their karyotypic details

\begin{tabular}{|c|c|c|c|c|c|c|c|c|c|c|}
\hline Cultivar & T.L & L & $\mathrm{S}$ & $\mathrm{L} / \mathrm{S}$ & TF\% & C.V & S\% & $\mathrm{X}$ & D.R.L & T.V \\
\hline 1. Kerman & 31.63 & 3.53 & 1.54 & 2.3 & 44.0 & 22.0 & 51.0 & 2.3 & 5.2 & 6.5 \\
\hline 2. Kashan 12 & 30.65 & 3.27 & 1.67 & 2.0 & 41.7 & 20.0 & 43.6 & 2.4 & 6.3 & 5.8 \\
\hline 3. Ghom 1 & 28.89 & 3.26 & 1.33 & 2.4 & 40.9 & 23.0 & 40.8 & 2.2 & 6.7 & 5.4 \\
\hline 4. Giroft & 28.31 & 2.97 & 1.42 & 2.1 & 41.5 & 19.3 & 47.0 & 2.1 & 5.5 & 5.1 \\
\hline 5. Garmsar 60 & 46.16 & 4.99 & 2.23 & 2.2 & 39.7 & 21.7 & 42.7 & 3.5 & 5.9 & 8.3 \\
\hline 6. Lasjard & 34.65 & 3.75 & 1.58 & 2.3 & 43.3 & 22.1 & 42.1 & 2.6 & 6.2 & 6.8 \\
\hline 7. Kerman B. & 35.23 & 3.80 & 1.72 & 2.2 & 41.2 & 22.0 & 45.2 & 2.7 & 5.9 & 6.5 \\
\hline 8. Neiriz R. & 36.10 & 4.31 & 1.73 & 2.5 & 42.5 & 26.1 & 40.1 & 2.7 & 7.1 & 6.6 \\
\hline 9. Ghom 52 & 37.44 & 4.81 & 1.76 & 2.7 & 42.9 & 30.1 & 36.4 & 2.8 & 8.1 & 7.0 \\
\hline 10. Neiriz GAZ & 35.82 & 4.26 & 1.58 & 2.7 & 38.7 & 28.5 & 37.0 & 2.7 & 7.4 & 6.6 \\
\hline 11. Shahrood & 38.10 & 4.30 & 1.66 & 2.59 & 40.0 & 26.0 & 38.6 & 2.9 & 6.9 & 7.2 \\
\hline 12. Damghan & 36.17 & 4.06 & 1.60 & 2.4 & 39.7 & 23.8 & 40.0 & 2.7 & 6.8 & 7.2 \\
\hline 13. Shahreza & 32.03 & 3.55 & 1.50 & 2.3 & 41.4 & 23.0 & 43.7 & 2.4 & 6.3 & 6.7 \\
\hline 14. Neishaboor & 37.42 & 4.28 & 1.67 & 2.5 & 39.6 & 26.0 & 39.1 & 2.8 & 6.9 & 8.2 \\
\hline 15. Ardekan 1 & 34.68 & 3.73 & 1.64 & 2.2 & 40.3 & 22.0 & 43.0 & 2.6 & 6.0 & 7.0 \\
\hline 16. Kashmar & 37.20 & 3.82 & 1.91 & 2.0 & 41.3 & 19.0 & 50.0 & 2.8 & 5.1 & 7.9 \\
\hline 17. Kerman G. & 37.61 & 3.97 & 1.82 & 2.1 & 41.4 & 21.8 & 45.8 & 2.9 & 5.7 & 7.9 \\
\hline 18. Hashemabad & 31.69 & 3.57 & 1.62 & 2.2 & 39.4 & 21.5 & 45.3 & 2.4 & 6.1 & 6.9 \\
\hline 19. Esfahan A. & 41.13 & 4.49 & 1.76 & 2.5 & 41.5 & 23.7 & 39.1 & 3.1 & 6.6 & 9.1 \\
\hline 20. Shooshtar & 36.16 & 4.05 & 1.72 & 2.3 & 42.1 & 21.7 & 42.4 & 2.8 & 6.3 & 8.0 \\
\hline 21. Gozagh & 35.30 & 3.66 & 1.73 & 2.1 & 42.1 & 21.1 & 47.2 & 2.7 & 5.4 & 7.7 \\
\hline 22. Mehrizsabz & 30.78 & 3.45 & 1.50 & 2.3 & 39.8 & 25.4 & 43.3 & 2.3 & 6.3 & 6.3 \\
\hline 23. Sabzevar & 35.74 & 4.05 & 1.76 & 2.3 & 40.5 & 26.0 & 43.5 & 2.7 & 6.4 & 7.4 \\
\hline 24. Marvast & 30.56 & 3.09 & 1.58 & 1.9 & 42.3 & 18.0 & 51.1 & 2.3 & 4.9 & 6.6 \\
\hline 25. Rafsangan & 42.66 & 4.73 & 1.95 & 2.4 & 40.4 & 25.2 & 41.2 & 3.2 & 6.5 & 9.0 \\
\hline 26. Mehrizbah & 42.77 & 4.96 & 1.56 & 3.1 & 40.6 & 28.3 & 31.4 & 3.3 & 7.9 & 9.3 \\
\hline 27. Ghomgermez & 30.35 & 3.24 & 1.60 & 2.0 & 40.2 & 21.5 & 49.3 & 2.3 & 5.4 & 6.1 \\
\hline 28. Mehrizgod & 30.08 & 3.48 & 1.36 & 2.5 & 41.5 & 25.0 & 39.0 & 2.3 & 7.0 & 6.1 \\
\hline 29. Ardekan 2 & 38.02 & 4.08 & 1.80 & 2.2 & 41.6 & 22.9 & 44.1 & 2.9 & 6.0 & 8.0 \\
\hline 30. Garmsar & 32.27 & 3.40 & 1.49 & 2.2 & 39.4 & 22.0 & 43.8 & 2.4 & 5.9 & 6.7 \\
\hline 31. Alyafrangi & 42.36 & 4.95 & 1.82 & 2.7 & 40.2 & 26.0 & 36.7 & 3.2 & 7.8 & 9.2 \\
\hline 32. Bandarabas & 38.23 & 4.48 & 1.64 & 2.7 & 41.5 & 28.6 & 36.6 & 2.9 & 7.4 & 7.6 \\
\hline 33. Rafsengan 2 & 34.50 & 3.90 & 1.72 & 2.2 & 43.1 & 24.0 & 44.0 & 2.6 & 6.3 & 6.8 \\
\hline 34. Rafsengan 3 & 35.14 & 4.13 & 1.59 & 2.6 & 41.7 & 27.6 & 38.5 & 2.7 & 7.2 & 7.1 \\
\hline 35. Harat & 40.82 & 4.71 & 1.95 & 2.4 & 39.7 & 24.0 & 41.0 & 3.1 & 6.7 & 8.2 \\
\hline 36. Ghom 3 & 40.18 & 4.79 & 1.82 & 2.6 & 39.2 & 27.0 & 38.0 & 3.1 & 7.4 & 7.9 \\
\hline 37. Sabzevar 1 & 46.46 & 5.03 & 2.01 & 2.5 & 41.3 & 24.8 & 39.9 & 3.5 & 6.5 & 9.3 \\
\hline 3.8 Arya & 27.80 & 2.71 & 1.71 & 1.5 & 43.2 & 16.2 & 63.0 & 2.1 & 3.6 & 5.2 \\
\hline 39. Mehrizgher & 30.63 & 2.91 & 1.75 & 1.6 & 43.9 & 13.5 & 60.1 & 2.3 & 3.7 & 6.0 \\
\hline 40. Mahalat & 23.83 & 2.40 & 1.20 & 2.0 & 40.2 & 17.3 & 50.0 & 1.8 & 5.0 & 4.7 \\
\hline 41. Mehriz 4 & 27.41 & 3.11 & 1.39 & 2.2 & 40.5 & 20.4 & 44.6 & 2.1 & 6.2 & 5.7 \\
\hline 42. Mehriz 5 & 30.77 & 3.46 & 1.53 & 2.2 & 43.2 & 21.1 & 44.2 & 2.3 & 6.2 & 6.0 \\
\hline
\end{tabular}

$\mathrm{T} . \mathrm{L}=$ Total length, $\mathrm{L}=$ longest chromosome, $\mathrm{S}=$ shortest chromosome, $\mathrm{TF} \%=$ total form percentage, $\mathrm{C} . \mathrm{V}=$ coefficient of variation, $\mathrm{X}=$ mean-chromatin length, D.R.L = different relative length, $\mathrm{T} . \mathrm{V}=$ total volume.

rence of structural changes of chromosomes among the cultivars and points towards their distinctness.

ANOVA based on factorial analysis of karyotypic data (Table 3), showed a significant difference among the cultivars.

All these results indicate presence of variation in genetic material of G. herbaceum cultivars both quantitatively (size differences) and qualitatively (structural changes), which can be used in hybridization programs to broaden the genetic variability of the gene pool. For this purpose cluster analysis can be used.

Dendrogram produced from UPGMA cluster analysis is presented in Fig. 2. In total 
Table 3. ANOVA for cultivars representative of clusters

\begin{tabular}{lccccc}
\hline Source & Degrees of freedom & Sum of squares & Mean square & F value & Prob. \\
\hline Cultivars & 5 & 46.833 & 9.367 & 2152.6249 & $* *$ \\
Chromosomes & 12 & 72.033 & 6.003 & 1379.5315 & $* *$ \\
Cultivar $\times$ Chromosome & 60 & 6.076 & 0.101 & 23.2724 & $* *$ \\
Error & 156 & 0.679 & 0.004 & & \\
\hline Total & 233 & 125.621 & & & \\
\hline
\end{tabular}

Coefficient of variation: $2.48 \%$.

ECLUCIDIAN DISTANCE
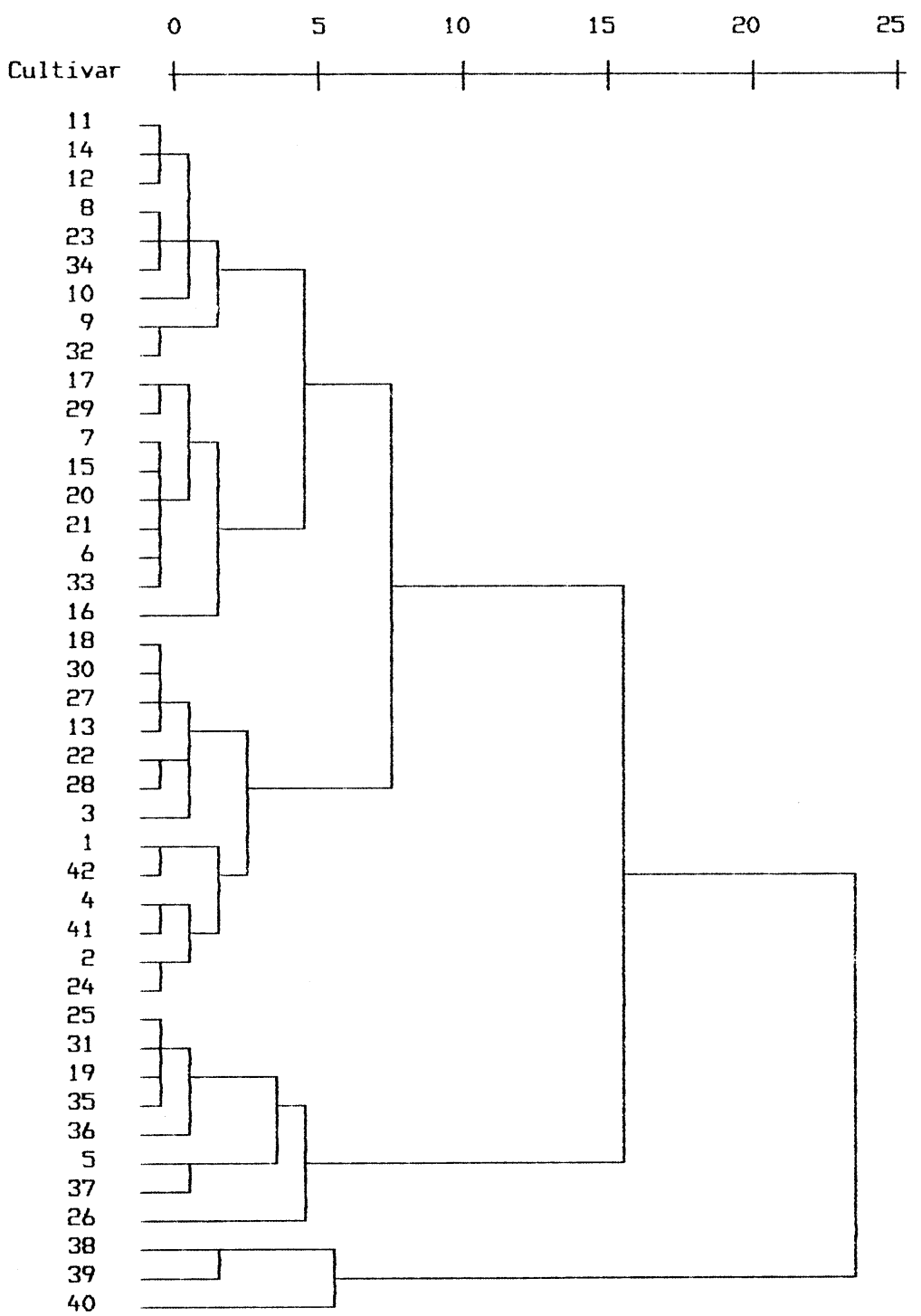

Fig. 2. UPGMA cluster analysis (cultivars sequence as Table 1). 
cultivars are grouped in six clusters. Nine cultivars are present in each of the first and second cluster, 7 cultivars in the third cluster, 6 in the forth, 8 in the fifth and 3 cultivars in the sixth cluster.

It is suggested to carry out different methods of clustering in order to recognise the real clusters (Ingrouille 1986, Rolf 1987). Other clustering methods such as single linkage and complete linkage was carried out for karyological data and the same results were obtained again indicating distinctness of the clusters (Rohlf 1987). Moreover fit of the clusters obtained to the original data was checked using cophenetic correlation (Stanton et al. 1994). Correlation obtained $(\mathrm{r}=0.82)$ indicates good fit of clusters.

Hybridization program can be arranged with crossing those cultivars placed in distant clusters (differ genetically). In this case members of the cluster 1 can be crossed with cluster 6 to get more variability and heterosis. It is interesting to note that culrivars also varied significantly with regard to many of the morphological characters studied including the yield in the first and second harvest (unpublished data). Presence of variability within G. herbaceum

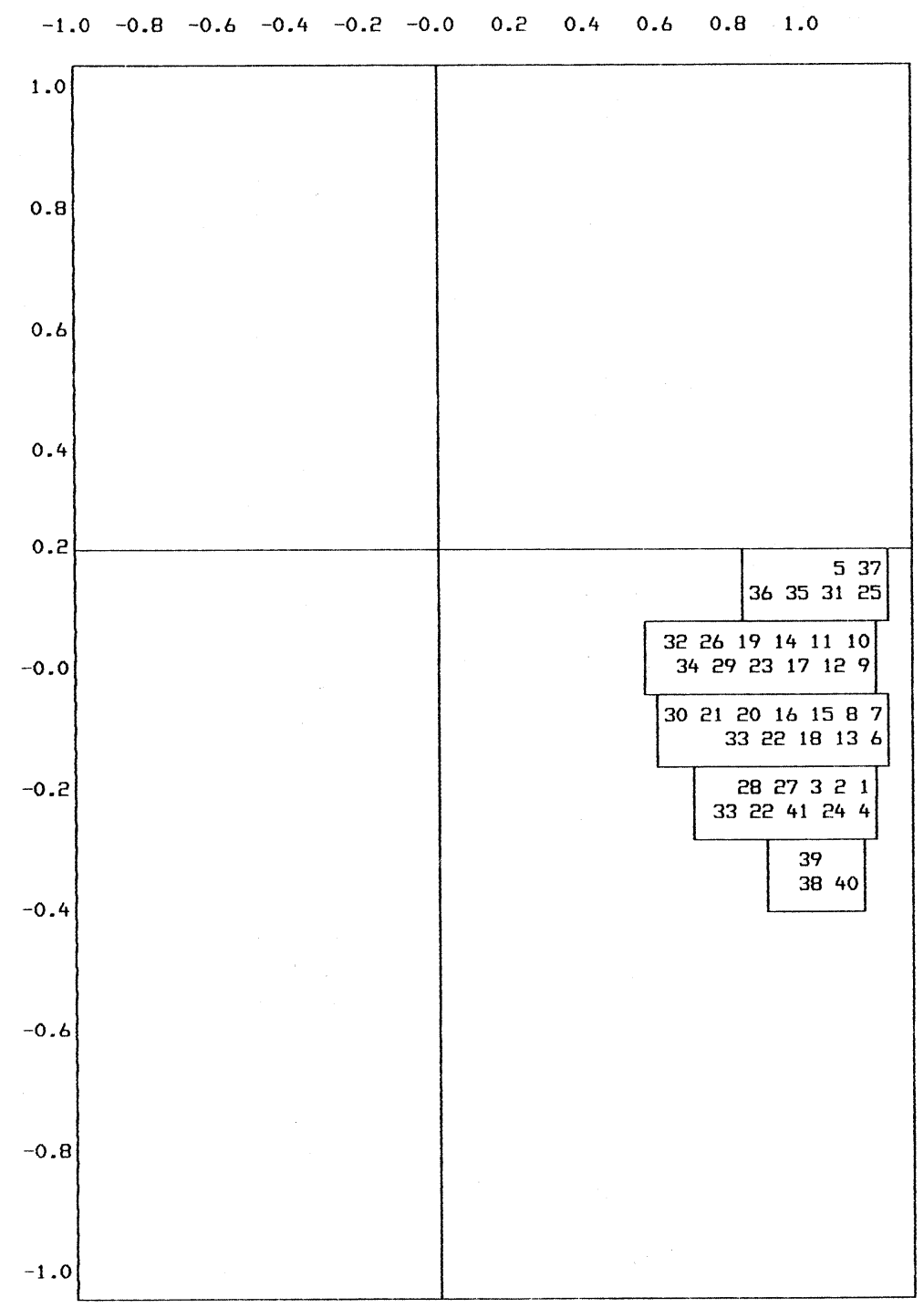

Fig. 3. Plot of cultivars on the first two principal coordinate axis. 
has also been noticed by Hutchinson (1950) and partitioned into infraspecific races based on a combination of geographical and morphological factors (Hutchinson 1950).

Grouping of the cultivars was also carried out using principal coordinate analysis. Cultivars were ploted against the first two PCO axis (Fig. 3). Grouping obtained from principal coordinate analysis is very similar to clustering result (Fig. 2) for example cultivars 38,39 and 40 which form cluster number six are grouped together, cultivars 5, 35, 36, 37 and 25 which belong to cluster number five are grouped together and so on.

Principal component analysis (PCA) was used to indicate the most variable characters (chromosome/chromosome arm) (Chatfield and Collins 1995, Sheidai et al. 1996b). Characters with high eigen values can be considered as the most variable one. For this analysis from each cluster (Fig. 2) a single cultivar was selected.

Eigen values obtained from PCA analysis are presented in Table 4. The first two PCA axis comprise $92 \%$ of the total variance, hence characters possessing high loadings from these two

Table 4. PCA eigen values ( $T L=$ total length, $L=$ long arm and $S=$ short arm)

\begin{tabular}{|c|c|c|c|}
\hline Character & & Eigen values & \\
\hline 1. T.L 1 & 0.9442355 & 0.3044422 & 0.0130737 \\
\hline 2. T.L 2 & 0.9435303 & 0.3207656 & 0.0654042 \\
\hline 3. T.L 3 & 0.9616423 & 0.2595112 & -0.0792506 \\
\hline 4. T.L 4 & 0.9802814 & 0.1661346 & -0.0995759 \\
\hline 5. T.L 5 & 0.9842811 & 0.1730213 & -0.0215702 \\
\hline 6. T.L 6 & 0.9761192 & 0.1459243 & 0.0623697 \\
\hline 7. T.L 7 & 0.9897339 & 0.0926357 & 0.0939711 \\
\hline 8. T.L 8 & 0.9893773 & -0.0947087 & 0.0445466 \\
\hline 9. T.L 9 & 0.9827799 & -0.1497337 & -0.0078519 \\
\hline 10. T.L 10 & 0.9720023 & -0.2260099 & -0.0302287 \\
\hline 11. T.L 11 & 0.9557984 & -0.2825199 & -0.0300870 \\
\hline 12. T.L 12 & 0.9611933 & -0.2506495 & 0.0361333 \\
\hline 13. T.L 13 & 0.9515376 & -0.1438370 & -0.0871166 \\
\hline 14. L 1 & 0.9296600 & 0.2994036 & 0.1796616 \\
\hline 15. L 2 & 0.9792231 & 0.1452155 & 0.0024225 \\
\hline 16. L 3 & 0.8932266 & 0.1047869 & 0.4004735 \\
\hline 17. L 4 & 0.9517452 & 0.0494204 & -0.0990247 \\
\hline 18. L 5 & 0.7984431 & 0.5938848 & 0.0705069 \\
\hline 19. L 6 & 0.8299985 & 0.5099703 & -0.1955794 \\
\hline 20. L 7 & 0.9094835 & 0.1631144 & 0.3615534 \\
\hline 21. L 8 & 0.9849548 & 0.0207943 & 0.1026338 \\
\hline 22. L 9 & 0.9603475 & 0.1289418 & -0.1504501 \\
\hline 23. L 10 & 0.9822197 & -0.0062697 & -0.0874987 \\
\hline 24. L 11 & 0.9388434 & -0.1774599 & 0.2415662 \\
\hline 25. L 12 & 0.9552200 & -0.2130226 & -0.1495943 \\
\hline 26. L 13 & 0.9899347 & -0.1180497 & -0.0139577 \\
\hline 27. S 1 & 0.6888841 & 0.3593750 & 0.3071804 \\
\hline 28. S 2 & 0.8473538 & 0.4375768 & -0.1500808 \\
\hline 29. S 3 & 0.9517440 & 0.0893563 & -0.0368498 \\
\hline 30. S 4 & 0.7864973 & 0.0694117 & -0.5154691 \\
\hline 31. S 5 & 0.7590390 & -0.3111688 & -0.4373530 \\
\hline 32. S 6 & 0.8489204 & -0.3566482 & 0.3624171 \\
\hline 33. S 7 & 0.9654807 & 0.0013565 & -0.2224166 \\
\hline 34. S 8 & 0.9307960 & -0.2570860 & -0.0210383 \\
\hline 35. S 9 & 0.8530551 & -0.4832312 & 0.1764230 \\
\hline 36. S 10 & 0.6502419 & -0.6928445 & 0.1186614 \\
\hline 37. S 11 & 0.8172904 & -0.3763670 & -0.3909865 \\
\hline 38. S 12 & 0.8808297 & -0.2938288 & 0.3629604 \\
\hline 39. S 13 & 0.8665577 & -0.1272617 & -0.1998353 \\
\hline
\end{tabular}




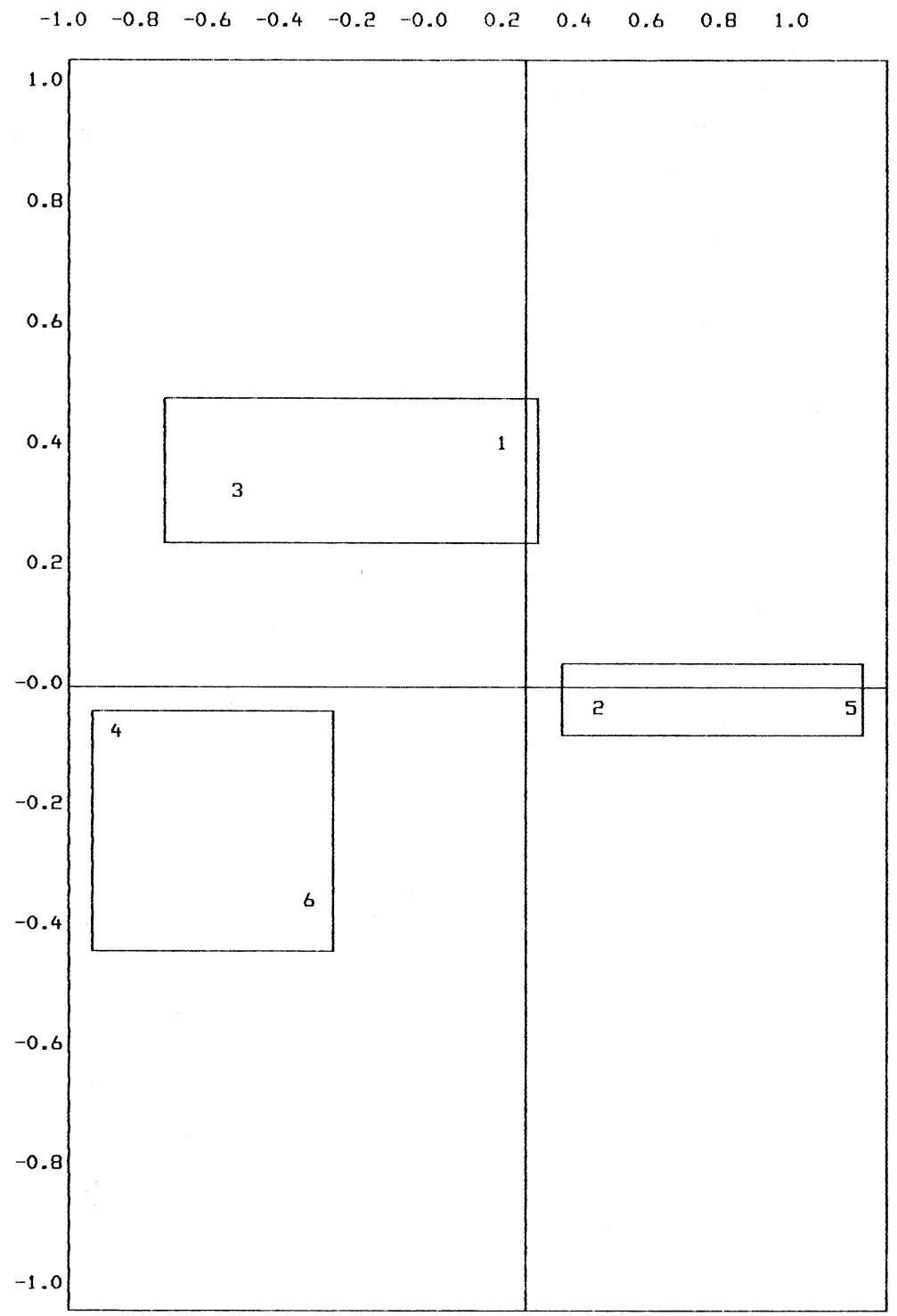

Fig. 4. Plot of cluster representatives on first two PCA axis $(1=$ cultivar $23,2=20,3=22,4=$ $4,5=5,6=39)$.

axis contribute to the karyotypic variations observed among the cultivars studied.

Result obtained (Table 4) indicates that total chromosome length of chromosomes 4 to 10 with high loading $(>0.98)$, long arms of the chromosomes $2,8,10$ and $13(>0.97)$ and short arms of the chromosomes 3,7 and $8(>0.95)$ are the most variable characters among the cultivars studied. Cophenetic correlation $>0.84$ indicates good fit of eigen values (Stanton et al. 1994).

Ordination of the cultivars selected from each cluster on the first two PCA axis is presented in Fig. 4. Separation of clusters are evident (for example cluster 1 from 6) indicating genomic differences.

Present work reports karyological analysis of the diploid Gossypium herbaceum cultivars of Iran for the first time, indicating their genomic differences. Crossing plan with regard to results obtained is in hand. 


\section{Summary}

Forty-two G. herbaceum cultivars available in Iran National Gene Bank were analysed karyologically showing $2 n=26$ chromosome number. The cultivars varied with regard to number of SAT-chromosomes and chromosomes carrying secondary constrictions. Karyotypes were of symmetrical type having small chromosomes. Factorial analysis showed significant difference for both the cultivars as well as chromosomes.

Cluster analysis using UPGMA, single linkage and complete linkage methods grouped the cultivars in six distinct clusters. Principal coordinate analysis supports the clustering results and principal component analysis showed that chromosomes 4 to 10 and long arms of the chromosomes 2, 8, 10 and 13 and short arms of the chromosomes 3, 7 and 8 are the most variable chromosomes/chromosome arms among the cultivars studied.

Present work indicates genomic differences among diploid G. herbaceum cultivars of Iran which can be used in hybridization programs. Crossing of the cultivars placed in distant clusters are suggested.

\section{References}

Bernardello, L. M., Heiser, C. B. and Piazzano, M. 1994. Karyotypic studies in Solanum section Lasiocarpa (Solanaceae). Amer. J. Bot. 81: 95-103.

Chatfield, C. and Collins, A. J. 1995. Introduction to Multivariate Analysis. Chapman and Hall. pp. 246.

Datta, M. and Agarwal, B. 1992. Intervarietal differences in karyotype of tea. Cytologia 57: 437-441.

Fitzgerald, P. J. 1989. Plant germplasm-An essential resource in our future. In Scientific management of germplasm: Characterization, evaluation and enhancement. Eds. H. T. Stalker, C. Chapman. Lecture series. 2. IBPGR training courses: Lecture series. 2. pp. 3-6. IBPGR. Rome.

Forni-Martins, E. R., Franchi-Tanibata, M. and Cardelli-de-Lucena, A. 1994. Karyotypes of species of Sesbania Scop. Cytologia 59: 13-18.

Gennur, M. N., Habib, A. F., Kadapa, S. N. and Goud, J. V. 1988a. Karyomorphological studies in Asiatic cottons. I. Karyotypic analysis of species and races of Asiatic cottons based on chromatin content. Cytologia 53: $97-$ 106.

- , - - - and - 1988b. Karyomorphological studies in Asiatic cottons. II. Karyotypic analysis of species and races of Asiatic cottons based on nucleolar chromosomes and symmetry of karyotype. Cytologia 53: 107-114.

Hutchinson, J. B. 1950. A note on some geographical races of Asiatic cottons. Emp. Cotton Grow. Rev. 27: $123-127$. Ingrouille, M. J. 1986. The construction of cluster webs in numerical taxonomic investigations. Taxon 35: 541-545.

Levan, A., Fredga, K. and Sandberg, A. 1964. Nomenclature for centromeric position on chromosomes. Hereditas 52: 201-220.

McClintock, K. A. and Waterway, M. J. 1994. Genetic differentiation between Carex lasiocrafa and C. pellita (Cypracea) in North America. Amer. J. Bot. 8: 224-231.

Pickersgill, B., Heiser, C. B. and McNeil, J. 1976. Numerical taxonomic studies on variation and domestication in some species of Capsicum. In The Biology and Taxonomy of the Solanaceae. Eds. J. G. Hawkes, R. N. Lester and A. D. Skelding. pp. 679-700. Academic Press, London, New York.

Rao, V. R. and Riley, K. W. 1994. The use of biotechnology for conservation and utilization of plant genetic resources. Rev. Plant Genetic Resources Newsletter 97: 3-19.

Rolf, F. J. 1987. NTSYS-pc. Numerical Taxonomy and Multivariate Analysis System for the IBM PC Microcomputer (and compatibles). ver. 1.40. Applied biostatistics Inc.

Sheidai, M., Ahmadian, P. and Poorseyedy, SH. 1996a. Cytological studies in Iran zira from three genus: Bunium, Carum and Cuminum. Cytologia 61: 19-25.

-, Massumi, A. R. and Pakravan, M. 1996b. Karyotypes of some Astragalus taxa (Sec. Xiphidium Bge.) from Iran. The Nucleus 39 (in press).

Sneath, P. H. A. and Sokal, R. R. 1973. Numerical Taxonomy. Freeman, San Francisco, pp. 573.

Stanton, M. A., Stewart, J. McD., Percival, A. E. and Wendel, J. F. 1994. Morphological diversity and relationship in the A-genome cotton, Gossypium arbereum and G. herbaceum. Crop. Sci. 34: 519-527.

Verma, B. N. 1980. Karyotype analysis in three species of Rhizoclonium Kutze. Cytologia 45: 433-440. 